\title{
Multibeam backscatter as a tool for seafloor characterization and identification of oil spills in the Galicia Bank
}

\author{
T. Medialdea ${ }^{a^{*}}$ L. Somoza ${ }^{\mathrm{q}}$ R. León ${ }^{\mathrm{a}}$, M. Farrán ${ }^{\mathrm{b}}$, G. Ercilla ${ }^{\mathrm{b}}$, A. Maestro ${ }^{\mathrm{a}}$, D. Casas ${ }^{\mathrm{b}}$, \\ E. Llave ${ }^{\mathrm{a}}$, F.J. Hernández-Molina ${ }^{\mathrm{c}}$, M.C. Fernández-Puga ${ }^{\mathrm{a}}$, B. Alonso ${ }^{\mathrm{b}}$ \\ ${ }^{a}$ Marine Geology Division, Instituto Geológico y Minero de España, IGME, Ríos Rosas 23, 28003 \\ Madrid, Spain. \\ ${ }^{b}$ Institute of Marine Sciences ICM-CSIC, Passeig Maritim de la Barceloneta, 37-49, E-08003 Barcelona, \\ Spain \\ ${ }^{c}$ Dpto. de Geociencias Marinas. Universidad de Vigo. E-36200 Vigo (Pontevedra)
}

\begin{abstract}
This study is focused on the potential of using the multibeam acoustic backscatter both for seafloor characterization of the Galicia Bank and for identification of seabottom oil spills. An extended multibeam data set was acquired during the RG-1 and RG-2 surveys aboard RV Hespérides in 2003 for the geological and geophysical characterization of the Galicia Bank, where the oil tanker Prestige wreck is located. 3-D images have been made by integrating bathymetry and backscatter data. Multibeam data have been additionally supported by gravity core information in order to correlate sea-floor acoustic backscatter with the surficial sediments and their physical properties. The major factors that seem to control the zonation of the backscatter intensity images are (i) the type of the sedimentary processes (gravitational, turbiditic, hemipelagic), which control at same time, the grain size distribution, and (ii) the seabottom morphologies, such as basement outcrops. However, there are some backscatter halos that can not be explained by these processes. In the backscatter maps, the bow and stern of the Prestige wreck are clearly marked by a high-backscatter intensity anomaly, whose existence is discussed.
\end{abstract}

Keywords: Galicia Bank; backscatter; oil tanker Prestige; sedimentary processes; oil spill 


\section{Introduction}

In the last several years, the integration of bathymetry and backscatter information has led to a revolution in our understanding of seabed features and sedimentary processes (Goff et al., 1999; Todd et al., 1999; Loncke et al., 2002; Hellequin et al., 2003; Nitsche et al., 2004). Multibeam sonar systems not only provide seafloor bathymetry and morphology, but also acoustic backscatter data that can reveal significant information for indirect seafloor characterization (e.g. Mitchell and Clarke, 1994; Goff et al., 2004). Seafloor acoustic response can be linked to seafloor roughness produced by features such as ripples, benthic reworking, etc. (Urick, 1975) and to physical properties of the surficial sediments (texture, dewatering, compaction, acoustic impedance, density, porosity, velocity). These properties are closely related, for example acoustic impedance is a function of velocity and density, which in turn depends on other properties such as compaction and porosity (Davis et al., 2002; Nitsche et al., 2004). Backscatter strength is also dependant on other instrumental parameters not linked to sea floor characteristics, like the angle of incidence of the beam at the seafloor or signal attenuation and abrupt changes in bathymetry (Lurton, 2002).

One of the most recent developments in the processing of multibeam data is its application to the discrimination between differing sediment types in order to predict seafloor facies (Dartnell and Gardner, 2004). It has been proposed that variations in grain size constitute the major contributor to changes in backscatter intensity. Typically the differences between muddy and rocky seafloor are on the order of 10-20 dB (Goff et al., 1999; 2000). However, recent regional studies have revealed that backscatter intensity may be influenced by other factors such as the occurrence of benthic fauna (Fenstermacher et al., 2001; Edwards et al., 2003; Kostylev et al., 2003; Valentine et al., 
2003), sediment compaction (Nitsche et al., 2004), the rate of the sediment reworking by organisms (Borgeld et al., 1999; Urgeles et al., 2002), the presence of anthropogenic organic residues (Lewis et al., 2000), the content of natural hydrocarbons in fluidventing structures such as mud volcanoes (Fonseca et al., 2002; Sager et al., 2003; Somoza et al., 2003) or the presence of authigenic carbonates related to the bacterial oxidation of methane (Orange et al., 2002; Díaz-del-Río et al., 2003).

In November 2002, the Prestige tanker, with 77.000 tonnes of fuel-oil, sank in the southwestern part of the Galicia Bank (western continental margin of Galicia) after splitting into two parts that lie $2 \mathrm{~km}$ apart: the bow at $3830 \mathrm{~m}$ and the stern at $3565 \mathrm{~m}$ depth (Fig. 1). During the sinking, 20000 tonnes of fuel were expulsed from the broken tankers and oil spills of up to $150 \mathrm{~km}$ spread over and reach the coast. In fact, oil was still leaking in July 2003, when the area was the object of an intensive multidisciplinary study by using different geophysical techniques as well as seabottom sampling. In this paper, we present a dense acoustic backscatter and bathymetric data set acquired in the southwestern part of the Galicia Bank over an area of $10 \mathrm{~km}$ by $9 \mathrm{~km}$ at $2790 \mathrm{~m}-4400 \mathrm{~m}$ depth. Multibeam data have been additionally supported by gravity core information in order to correlate seafloor acoustic backscatter with the surficial sediments and their physical properties.

The main objectives of this work are to characterize qualitatively the seafloor of the study area by means of backscatter imagery and to identify the causes of backscatter spatial variations which will provide a better understanding of the present sedimentary processes related to deep-water systems. In this study, a secondary goal has been to evaluate the potential of using the acoustic backscatter intensity in detailed surveys in deep water, taking into account that the majority of studies had been developed so far for shallow water, where bedforms and sediment variability offers interesting images of 
the seafloor. Considering that backscatter can be determined by acoustic impedance, it has also been considered that perhaps oil spills over/underlying the seafloor could be identified by changes in backscatter intensity.

\section{Geological background}

The Galicia Bank is an elongated basement high, which separates the Interior Basin from the Iberia Abyssal Plain (Fig. 1). The Galicia Bank, with its main axis oriented N-S, constitutes a horst in the continental slope that emerges from a depth of $3.800 \mathrm{~m}$ and reaches $<500 \mathrm{~m}$ at its summit. In the study area, which corresponds to the southwestern part of the Galicia Bank, the continental basement is affected by a major normal fault, which produces a scarp (Fig. 1) and delineates, to the west, a N-S halfgraben (Vázquez et al., this volume), slightly tilted to the east and filled with Mesozoic (Valanginian) to Holocene sediments (Mauffret et al., 1978; Groupe Galice, 1979; Boillot and Malod, 1988; Ercilla et al., this volume).

From the geomorphologic point of view, the study area is characterized in the eastern sector by an outstanding NNW-SSE crest that belongs to the SW flank of the Galicia Bank (Fig. 1). This elevation extends between 2790 and $3200 \mathrm{~m}$ depth and is bounded to the west by a roughly $\mathrm{N}-\mathrm{S}$ steep fault scarp, where basement outcrops and gravitational scars are often found. The scarp shows an initial slope of $6^{\circ}-13^{\circ}$ that progressively dips towards its base, where it reaches $29^{\circ}$. West of this scarp and at approximately right angles, a set of E-W sedimentary lobes (according to Llave et al., this volume), separated by inter-lobe channels, have developed in the central sector. These morphological features are the result of submarine mass movements (HernándezMolina et al., this volume). The channels end at a main channel trending NNE-SSW, 
which crosses obliquely the western sector of the study area. A more detailed description of the morphology can be found in Llave et al. (this volume).

It has been derived, from the morphological and seismic facies analysis, that the dominant processes in the study area are erosive, gravitational and depositional (Ercilla et al., 2004). The study of the recent sediments has been carried out with gravity cores obtained between 3104 and $4171 \mathrm{~m}$ depth and situated at the fault scarp, inter-lobe channels, sedimentary lobes and main channel. Turbidites characterize the upper Pleistocene-lower Holocene deposits and hemipelagites, hemiturbidites and pelagites the Holocene record (Alonso et al., this volume).

\section{Data and methodology}

A multibeam data set was acquired during RG-1 and RG-2 surveys along a dense grid of E-W and N-S lines, 250 and $650 \mathrm{~m}$ spaced. The surveys were conducted aboard the RV Hespérides in July and August, 2003 using a hull-mounted Simrad EM12S-120 multibeam echosounder, which allows simultaneous collection of high resolution seafloor bathymetry and backscatter strength measurements. The system operated at a frequency of $13 \mathrm{kHz}$ and utilized 81 beams, equispaced, with a swath width of $120^{\circ}$, which was reduced to $90^{\circ}$ close to the sunken tanker. Beams were electronically controlled for pitch and roll stabilization. Vertical resolution was approximately $0.025 \%$ of water depth. Acoustic footprint of the system varies in size

with water depth and the beam angle. In the study area, footprint was approximately 100-200 $\mathrm{m}$ at $3500 \mathrm{~m}$. Middle- and high-resolution seismic profiles were simultaneously obtained with air gun and Topas (TOpographic PArameter Sonar) systems respectively. A GeoAcoustics Sonar Enhancement System (SES) and Triton- 
Elics Delph software were used for seismic acquisition and processing. Ship positioning was achieved with a Differential Global Positioning System.

Multibeam data were acquired using Simrad's Merlin software. Several sound velocity profiles were measured by means of expandable bathythermographic sounders (SIPPICAN MK-12) for depth calculation. Bathymetric data were processed with Simrad Neptune software. The processed data were gridded using ordinary krigging interpolation method with a grid spacing of $10 \mathrm{~m}$ and contoured using ArcInfo software with a $10 \mathrm{~m}$ interval depth.

Backscatter signal amplitudes were corrected with Simrad's Poseidon software for the transmitted source level, acoustic beam patterns and the transmission loss in the water column (http//www.konsberg.con/eng/kog). Local-slope corrections were not applied in the backscatter - processing scheme. Taking into account the ensonified area, angular backscatter strength was calculated for each beam (Mitchell, 1996; Lurton, 2002).

The backscatter processing scheme comprised the following steps: a) removing the incorrect soundings and their corresponding side scan sonar values, b) weight averaging values in overlapping lines, and c) removing side-scan sonar returns outside angles $\left(>70^{\circ}\right)$ to eliminate the distorted data. We have not performed any smoothing or filtering because the data distance $(15-20 \mathrm{~m})$ was less than the footprint $(150 \mathrm{~m})$, as a result of an overlap ratio of $85 \%$ between track lines. Backscatter image cell size was 10 m. We only used data from $75 \%$ of the footprint on either side of the athwartships center line. Pixel reduction method for data values gathered was averaged from all values recorded in the cell.

All data have been loaded into a Geographic Information System (ArcInfo) to visualize and analyse the georeferenced data sets (topographic, backscatter and 
navigation data), for map generation and to produce the digital terrain models and 3D images.

Variations in backscatter intensity are displayed in a map (Fig. 2A), which has been built up taking into account the entire side-scan sonar data set processed with Simrad Poseidon software. Eventually and in order to accentuate differences between backscatter values and to eliminate noise, a second map was produced calculating mean backscatter strength values by a statiscal analysis carried out with GIS ArcInfo software (Fig. 2B). This analysis were performed over a grid of $150 \mathrm{~m}$, assuming this value as the horizontal resolution of the Simrad EM12S-120 multibeam echosounder for a water depth of $3.500 \mathrm{~m}$. Mean values were calculated using neighbourhood statistics.

Backscatter intensity has been represented in both maps by the same suite of colours, ranging from blue (low intensity) to red (high intensity). Backscatter intensity ranges from -45 to $-18 \mathrm{~dB}$. Since most of the acoustic returns are concentrated between 37 and $-31 \mathrm{~dB}$, the colour scale has been fixed with the purpose of enhancing these short-term changes. With this aim, backscatter data were segmented by seven quantiles (standard deviation of 3.54) to enhance the acoustic response differences.

In order to correlate backscatter information to bottom properties, the multibeam data set has been supported with 16 gravity cores (3-5 m long) obtained during the RG1 and RG-2 surveys that were analyzed for grain size measurements. The length of the cores recovered varies between 0.6 and $2.9 \mathrm{~m}$. Textural analysis were performed using settling-tube techniques for the coarse-grained fraction (> $50 \mathrm{um}$ ) and Sedigraph-X ray techniques for the fine-grained fraction. Besides, physical properties of the sediments, including parameters as density and compressional velocity ( $\mathrm{Vp}, \mathrm{p}$-wave) were recorded with a Multi-Sensor Core Logger in most of the cores (Alonso et al., this volume). 


\section{Results}

Study of the variability in backscatter strength and its distribution has been accomplished by the analysis of maps and 3D images for seabottom characterization.

\subsection{Backscatter imagery}

An overall view of the side scan sonar map enables us to define two areas having acoustic differences of about $10 \mathrm{~dB}$ (Fig. 2A): an eastern region $\left(12^{\circ}-12^{\circ} 3^{\prime} \mathrm{W}\right.$ ) with average values of -18 and $-28 \mathrm{~dB}$ (red colour) and a wider region to the west $\left(12^{\circ} 3^{\prime}-\right.$ $12^{\circ} 10^{\prime} \mathrm{W}$ ), with lower backscatter values between -37 and $-31 \mathrm{~dB}$ (bluish orange tones). This image is similar to the sonograph obtained using the Towed Ocean Bottom Instrument (TOBI) presented by Hernández-Molina et al. (this volume) (Fig.3), even though backscatter intensity is not as homogeneous.

On the mean backscatter strength map (Fig. 2B), the same regional backscatter pattern can also be defined, although some differences arise from the comparison between both maps (Figs. 2A and B). It appears that the mean backscatter strength map marks more neatly the differences in backscatter values in the western region (Fig. 2B), that depict the main morphological features such as the inter-lobe channels, sedimentary lobes, the scarp, the ridge crest and the main channel (Figs. 1 and 2B). On the other hand, the limits of the higher backscatter strength zones, related to the fault scarp of the Galicia Bank, are better outlined in relation to the surrounding zones. Consequently, it can be derived that subtle changes in backscatter strength are emphasized using mean backscatter values.

Superposed on this backscatter pattern, there are two high-backscatter anomalies that can be correlated to the bow and stern of the sunken tanker (Figs. 2A and B). This 
is a relevant fact if we take into account that the multibeam footprint is bigger than the ship's wreck (each part of the ship's wreck is about $120 \mathrm{~m}$ long).

\subsection{Backscatter and morphology}

In order to link acoustic response to seafloor morphology, a 3D image has also been produced by integrating bathymetry and mean backscatter strength (Fig. 4). Based on this integration, four different zones can be recognized:

A) High-backscatter strength zones (from -19 to $-33 \mathrm{~dB}$ ): These values are reached at the fault scarp of the Galicia Bank (3000 m-3800 m depth) in the eastern sector, following a N-S direction. Values of -23 to $-32 \mathrm{~dB}$ predominate, whereas values between -18 and $-20 \mathrm{~dB}$ are found in the steepest areas of the scarp. Therefore probably steep slopes enhance high backscatter. This backscatter response is also found in the westernmost sector, along the southern segment of the main NNE-SSW main channel (Fig. 4).

B) High to medium backscatter strength zones (from -32.5 to $-35.5 \mathrm{~dB}$ ): They are very dispersed and are found: 1) at the main channel, 2) at the inter-lobe channels head, 3) on the top and flanks of the sedimentary lobes following a N-S direction close to the fault scarp in the southern part, and 4) at the distal parts of the sedimentary lobes (Fig. 4).

C) Medium to low backscatter strength zones (from -37.5 to $-38.5 \mathrm{~dB}$ ): This acoustic response is distributed along the sedimentary lobes and on the eastern flank of the main channel (Fig. 4).

D) Low backscatter strength zones (from -38 to $-40 \mathrm{~dB}$ ): This zone surrounds the highest backscatter strength zones at the fault scarp of the Galicia Bank and on 
the top of this structural high (Fig. 4). These values are also found in the southernmost sedimentary lobe and at the foot of the fault scarp, where its external undulated boundary seems to delineate small sedimentary wedges.

Taking into account the morphology and distribution of backscatter strength, we attribute zone A to basement outcrops located in the fault scarp and erosive areas of the main channel and zones $\mathrm{C}$ and $\mathrm{D}$ to sedimentary lobes and wedges. The distribution of high to medium backscatter strength zones (zone B) seems to be concentrated in areas susceptible to erosive processes and will be discussed later. The occurrence of these processes has also been suggested by TOBI side scan sonar data and the acoustic facies analyses of the near-surface sediments carried out in the same area by HernándezMolina et al. (this volume).

\subsection{Backscatter and sediments (grain size and physical properties)}

From a comparison with the backscatter values obtained in other studies (Goff et al., 2000; Urgeles et al., 2002; Nitsche et al., 2004), we can interpret that coarse sediments and basement outcrops situated at the fault scarp are responsible for the high acoustic response (zone A). On the other hand, the low to medium acoustic response in zones $\mathrm{B}, \mathrm{C}$ and $\mathrm{D}$ suggests the occurrence of a quite homogenous muddy sedimentary drape (Fig. 4). In these later zones, differences in backscatter strength are represented by variations of few $\mathrm{dB}$, giving rise to a more diffuse zonation.

This analysis of the signal amplitude has been supported with the gravity cores that ground truth the interpretation of the backscatter map (Fig. 5 and Table I). With this aim, location of cores has been superposed on the backscatter map (Fig. 5), confirming the above proposed interpretation. Hemiturbiditic muds $(<40 \mathrm{~cm}$ thickness $)$ are found at 
the top of the cores, evolving to hemipelagic and pelagic muds to the west $(18-40 \mathrm{~cm}$ thickness) and turbiditic sands to the east at the fault scarp (12-30 cm thickness). Shallow subbottom sediments are chiefly constituted by turbiditic muds $(40-160 \mathrm{~cm}$ thickness) (Alonso et al., this volume).

We have also attempted to interpret the potential relationship between backscatter and different sediment parameters such as grain size distribution, compressional velocity and density. These relationships have been analyzed by plotting different parameters versus backscatter strength (Figs. 6 and 7, Table I).

According to Table I, the lower backscatter values, between -37 and $-35.55 \mathrm{~dB}$ correspond to sands (1TG4, Fig. 5) and muddy sands and muds (1TG2 and 1TG3, Fig. 5) obtained in cores at the fault scarp of the Galicia Bank, whereas backscatter values between -32 and $-35 \mathrm{~dB}$ are associated with muds, which is the predominant sediment in the study area. Consequently, on a first approach grain size does not seem to correlate positively with acoustic backscatter. This is not in agreement with other studies, which generally show an overall increase in backscatter strength with grain size (Goff et al., 2000). However, only one sandy sample (1TG4, Fig. 5) was taken at the fault scarp close to the areas of higher reflectivity. Therefore, perhaps it is too tentative to establish that relationship, especially if we consider that basement outcrops interpreted in the seismic profiles coincide with the highest backscatter strength (Fig. 5).

When we plot backscatter intensity versus coarse (gravel+sand), it is difficult to establish at a first glance a good correlation between backscatter intensity and the weight percentage (Fig. 6). Nevertheless a closer examine allows us to differentiate two populations that mark two trends. The first population (P1) is composed of samples which have been classified as sands, muddy sands and muds (1TG2, 1TG3 and 1TG4) and in this case, backscatter exhibits a positive linear dependence with the coarse $\%$. 
They correspond to cores taken at the fault scarp. The second trend is delineated by muddy samples (P2) collected westwards, whose variation in grain size composition is small (low coarse \% and 86-93 fine \%). In relation to P2 (Fig. 6), it is difficult to discern if there is any dependence with coarse $\%$ and fine $\%$, as all samples have a very similar weight percentage. Then we propose that the coarse content represents a primary control on the backscatter in sandy or muddy sand samples. Nevertheless, in mud samples backscatter variability is apparently determined neither by fine $\%$ nor coarse $\%$. Therefore other factor than grain size must control backscatter.

Compressional velocity and density that determine the acoustic impedance have been also plotted against backscatter strength (Fig. 7A and 7B). It is derived from Fig. 7A an inverse correlation of backscatter and density. Once more two populations or groups of samples can be recognized (P1 and P2). The trend defined by P1 clearly marks the relation between density and backscatter. The second population (P2) is composed of samples with a similar density of $1.60 \pm 0.02 \mathrm{~g} / \mathrm{cm}^{3}$ and variations in backscatter values of the order of $2 \mathrm{~dB}$. This later population (1TG9, 1TG10 and 1TG11, Fig. 5) is located very close to the bow of the Prestige wreck, which induces an anomaly in the calculation of the mean backscatter value, that it is neatly exhibited in the map (Fig. 5). Finally, the comparison of compressional velocity to backscatter does not yield any clear relationship between both parameters (Fig. 7B).

\section{Discussion}

\subsection{Regional backscatter zonation}


The combined interpretation of the bathymetric and backscatter maps, and sediment properties derived from core logs, allow us to establish the relationship between the regional backscatter zonation, the morphology and sedimentary processes along the southwest Galicia Bank area (Figs. 4, 5 and 8).

Basement outcrops (BO in Figs. 5 and 8) of the Galicia Bank scarp are well defined by a narrow band of high backscatter ( -19 up to $-32 \mathrm{~dB})$ in the eastern region. They are interdigitized with low to medium backscatter patches (between -36 and -38 dB). These patches correspond to biogenic sands, sandy muds and muds (cores 1TG2, 1TG3 and 1TG4), being observed that backscatter values in this area are positively correlated to coarse fraction \%. Basement outcrops are bounded westwards by a strip of low backscatter that corresponds to several sedimentary wedges (SW in Fig. 5) plastered over the toe of the scarp. These wedges are interpreted to be related to gravitational processes associated to the erosion and dismantling of the scarp (according to Hernández-Molina et al., this volume) and are draped by hemipelagic muds, which generate low backscatter zones.

Westwards off the fault scarp, the morphology is characterised by E-W sedimentary lobes (SL in Figs. 5 and 8) and inter-lobe channels (IC in Fig. 5), that clearly show an overall decreasing in backscatter intensity with respect to the fault scarp in the eastern sector (Figs. 4 and 5). The top of the cores taken in the central and western sector is made up of muds.

In spite of the lower backscatter values, it is possible to recognize in the map, some bands of higher backscatter strength (Fig. 5). Three strips, E-W and ENE-WSW oriented, are found in the northern and southern part of the study area; they can be correlated to erosive processes at the inter-lobe channels. A band of higher backscatter at the distal parts of the sedimentary lobes could be associated with the erosion 
produced by the main channel. In fact, on seismic lines, reflectors of the western end of the sedimentary lobes appear truncated in this area (Fig. 8). Unfortunately we only have one core (2TG5 in Fig. 8) in these high-backscatter zones, nevertheless it shows one of the highest coarse weight percent among the muddy cores.

These strips of high backscatter strength surround a central area of medium to low backscatter (Fig. 5), where two N-S bands of higher backscatter (marked with dotted lines at $12^{\circ} 4^{\prime} \mathrm{W}-12^{\circ} 6^{\prime} \mathrm{W}$ in Fig. 5) have been identified crossing the inter-lobe channels and the sedimentary lobes. In this central area, the backscatter range is very narrow and not dependent on the grain size (Fig. 6). It is likely that some other factor than grain size is controlling backscatter variations in this area. In this sense, some proposals can be put forward, although none appears to justify completely the obtained results. Taking into account that differences in backscatter intensity are not related to grain size nor to compressional velocity, but to density, it could be considered that changes might be assigned to sea-bottom or near subbottom roughness, perhaps generated by bioturbation or other physical factor, like compaction. Seismic sections (Fig. 8) show that sedimentary lobes are composed of high-reflectivity layers interbedded with low-reflectivity deposits (Hernández-Molina et al., this volume). In this sense, one could hypothesize that perhaps more consolidated layers from these sedimentary lobes became exposed as a consequence of erosive processes active at present. This statement must be rejected as according to the core analysis, the surficial blanket of the sedimentary lobes and inter-lobe channels correspond to hemiturbiditic muds and hemipelagic muds. This blanket could be correlated with TOBI side scan sonar data which collected a quite homogeneous backscatter response (HernándezMolina et al., this volume). At this point, we will like to remember that data obtained from TOBI side scan sonar systems are directly related to the nature of the present 
seafloor. Likewise, we have to take into account that a $13 \mathrm{kHz}$ multibeam signal probably penetrates into sediment some variable depth (Barthelemy and Pockalny, 2002), introducing interferences from the subbottom heterogeneities and making difficult the interpretation of backscatter differences. The same proposal has been suggested by Ercilla et al. (1998) for the sedimentary lobes of the Orinoco Fan, where variations in backscatter have been associated to the presence of high amplitude subbottom reflections at $=3 \mathrm{~m}$ depth. Considering that most of the cores are wholly composed of muds, with only three exceptions, that contain thin sandy layers (Alonso et al., this volume), the heterogeneities should be found at more than $285 \mathrm{~cm}$ depth, which is the maximum core length in the zone. In consequence, longer cores will improve and constrain the evaluation of backscatter variations.

The westernmost sector shows medium to high backscatter intensity reflecting the location of the so-called main channel following a NNE-SSW direction (MC in Fig. 5). This high-backscatter area is also observed on the high-resolution seismic profile (Fig. 8) and is related to erosional processes along the main channel.

The major factor that seems to control the zonation of the backscatter in the study area is the type of sedimentary process, which control at the same time, the sediment type, the grain size distribution and the seabottom morphologies, although we must bear in mind that acoustic sources are able to penetrate into sediments. However, there are some anomalous halos that can not be explained with the existing pattern of deep-sea sedimentary processes related to the Galicia Bank scarp.

\subsection{Backscatter anomalies related to the Prestige shipwreck}


It is clearly observable that the stern and especially the bow of the Prestige wreck are marked by high-backscatter anomalies (Figs. 4B and 5). The most outstanding anomalies are surrounding the bow and correspond to N-S elongated halos in the central sector $\left(12^{\circ} 4^{\prime} \mathrm{W}\right)$, that extend over the sedimentary lobes and inter-lobe channels. Data from cores taken in this "shipwreck-related halo" show that there is no correlation between the backscatter intensity values and sediment properties such as grain size, density or compressional velocity "Vp" (Figs. 6 and 7). On the other hand, middle-resolution seismic profiles show a high-amplitude anomaly signal at the seabottom related to the presence of the bow of the Prestige wreck (Fig. 8) caused by a strong contrast of acoustic impedance. Moreover, a detailed study also shows a "brightspot" or amplitude anomaly located on the seawater column at $250 \mathrm{~m}$ above the shipwreck (Fig. 8). In this figure, a coloured scale has been assigned to amplitude values, confirming an important amplitude anomaly over the bow caused by a strong contrast of acoustic impedance. Taking into account that 57.000 tonnes of fuel-oil remain in the tankers after the sinking and that fuel-oil was escaping from November, 2002 to June, 2003, we interpret this as fuel-oil ascending from the bow. We would like to point out that all seismic profiles seem to reflect the presence of an acoustic disturbance by fuel-oil in the water column close to the bow. However, we can not be certain that the seabottom backscatter anomalies might also be related to the expulsion of fuel-oil. In this case, although we have not found any trace of fuel-oil in the cores (Ercilla et al., 2006), it is possible that scattered patches have fallen out to the seabottom after the fuel-oil comes in contact with the cooler Middle North Atlantic Deep Water (MNDW) at an average temperature of $2.6^{\circ} \mathrm{C}$ (Díaz-del-Río et al., 2003). Another explanation to be considered for the presence of this elongated halo might be related to processes produced by deep-water currents along slope of the Galicia Bank. In this way, 
the MNDW water mass moves toward the northeast at a maximum speed of $15 \mathrm{~cm} / \mathrm{s}$, but there is no significant evidence in seismic sections of contourite deposits. Finally and considering the detailed image provided by a multibeam system (Fig. 9), we can propose an additional explanation for at least part of the seabottom halo. This image clearly shows how the Prestige tanker slid downslope forming an elongated scar of up to $370 \mathrm{~m}$ and $3 \mathrm{~m}$ of relief. Therefore part of the anomaly could be interpreted as caused by the impact and slide of the bow. Nevertheless this explanation does not justify the NS direction that adopts the anomaly, and can only be applied to the ship's wreck area.

\section{Conclusions}

Backscatter pattern has been interpreted in terms of different types of sediment, physical properties, sedimentary processes and morphology and their variations in spatial distribution. High backscatter has been recorded from bedrock and sands and low backscatter from muddy seafloor. The highest backscatter values are related to basement outcrops at the fault scarp, whereas the lowest are associated to depositional facies corresponding to the sedimentary lobes and wedges. High to medium backscatter values can be associated to rough surfaces caused by erosional features or massmovement processes.

Two high-backscatter anomalies have been correlated to the bow and stern of the Prestige. It can not definitely settle from the results obtained in the Prestige's wreck area, if multibeam techniques are suitable to identify oil spills. We think that further studies needs to be developed to check if multibeam echosounders can be used successfully with this aim. Especially, it would be important to carry out studies to 
determine spatial and temporal backscatter variations and make a comparison between the different acquired data sets.

In summary, acoustic response can provide additional and valuable information on the distribution of sediment types and sedimentary developing processes at the sea floor. However, sediment samples are indispensable not only to check backscatter interpretation but also to discern which sedimentary processes are active at present, if we take into account that the multibeam sounder can penetrate into shallow subbottom sediments and influence backscatter values. Although additional data, such as bottom photographs, longer cores, etc. are needed to verify the cause of backscatter differences, it is derived from the results presented in this paper that the combination study of seafloor samples, backscatter intensity, bathymetry and morphology holds an important potential to remotely characterise seafloor sediments and sedimentary processes in deep waters.

\section{Acknowledgements}

This work was supported by the Comisión de Coordinación Científica (MEC) Special Action and CICYT (MEC) ERGAP project (Ref. VEM 2003-20093-CO3) titled Identificación de riesgos geoambientales potenciales y su valoración en la zona de hundimiento del buque Prestige (Identification of Potential Geoenvironmental Risks in the Sinking Zone of the Prestige, and their Assessment). This work is also a contribution to the Consolider-Ingenio 2010 CSD2006-0041-“TopoIberia". The authors thank all those who participated in the RG-1 and RG-2 research cruises, and the captain and crew of RV Hespérides. We are also grateful to the UTM for its technical support, especially to Pablo Rodríguez. We are grateful to Dr. F. Chiocci and Dra. J. Gardner, whose review significantly improved the earlier version of the manuscript.

\section{References}

Alonso, B., Ercilla, G., Casas, D., Estrada, F., Farrán, M., García, M., Rey, D., Rubio; 
B., This volume. Late Pleistocene and Holocene sedimentary facies on the SW Galicia Bank (Atlantic NW Iberian Peninsula). Mar. Geol.

Barthelemy, M., Pockalny, R., 2002. Regional analysis of backscatter data from the Southwest Pacific. Graduate School of Oceanography. GSO Technical Report no. 2003-1, 1-6.

Boillot, G., Malod, J., 1988. The north and north-west Spanish Continental Margin: A review. Rev. Soc. Geol. España 1(3-4), 295-316.

Borgeld, J.C., Hughes Clarke, J.E., Goff, J.A., Mayer, L.A., Curtis, J.A., 1999. Acoustic backscatter of the 1995 flood deposit on the Eel shelf. Mar.Geol. 154, 197-210.

Davis, A., Haynes, R., Bennell, J., Huws, D., 2002. Surficial seabed sediment properties derived from seismic profiler responses. Mar. Geol. 182, 209-223.

Dartnell, P; Gardner, J.V., 2004. Predicting seafloor facies from multibeam bathymetry and backscatter data. Photogramm. Eng. Rem. S. 70 (9), 1081-1091.

Díaz-del-Río, V., Somoza, L., Martínez-Frías, J., Mata, M.P., Delgado, A., HernándezMolina, F.J., Lunar, R., Martín-Rubí, J.A., Maestro, A., Fernández-Puga, M.C., León, R., Llave, E., Medialdea, T., Vázquez, J.T., 2003. Vast fields of hydrocarbon-derived carbonate chimneys related to the accretionary wedge/olistostrome of the Gulf of Cádiz. Mar. Geol. 195, 177-200.

Edwards, B. D., Dartnell, P., Chezar, H., 2003. Characterizing benthic substrates of Santa Monica Bay with seafloor photography and multibeam sonar imagery. Mar. Environ. Res. 56 (1-2), 47-66.

Ercilla, G., Alonso, B., Baraza, J., Casas, D., Chiocci, F.L., Estrada, F., Farrán, M., Gonthier, E., Pérez-Belzuz, F., Pirmez, C., Reeder, M., Torres, J., Urgeles, R., 1998. New high-resolution acoustic data from the "braided system" of the Orinoco deep sea fan. Mar. Geol. 146, 243-250.

Ercilla, G. and Grupo Prestige, 2004. Identificación de riesgos geoambientales potenciales y su valoración en la zona de hundimiento del buque Prestige. Geotemas 6 (5), 271-274.

Ercilla, G., Córdoba, D., Gallart, J., Gracia, E., Muñoz, J.A., Somoza, L., Vázquez, J.T., Vilas, F. and Grupo Prestige, 2006. Geological characterization of the Prestige sinking area. Mar. Pollution Bul. 53, 208-219.

Ercilla, G., García-Gil S., Estrada F., Gràcia, E., Vizcaino A., Vázquez, T., Díaz S., Vilas, F., Casas, D., Alonso, B., Dañobeitia, J., Farrán, M., This volume. Highresolution seismic stratigraphy of the Galicia Bank Region and neighbouring abyssal plains (NW Iberian continental margin).Mar. Geol..

Fenstermacher, L.E., Crawford, G.B., Borgeld, J.C., Britt, T., George, D.A., Klein, M.A., Driscoll, N.W., Mayer, L.A., 2001. Enhanced acoustic backscatter due to high abundance of sand dollars, Dendraster excentricus. Mar. Georesour. Geotec. 19 (2), 135-145.

Fonseca, L., Mayer, L., Orange, D., Driscoll, N., 2002. The high-frequency backscattering angular response of gassy sediments: Model/data comparison from the Eel River Margin, California. J. Acoust. Soc. Amer. 111 (6), 26212631.

Goff, J.A., Orange, D.L., Mayer, L.A., Hughes Clarke, J.E., 1999. Detailed investigation of continental shelf morphology using a high resolution swath sonar survey. The Eel margin, northern California. Mar. Geol. 154, 255-269.

Goff, J.A., Olson, H.C., Duncan, C.S., 2000. Correlation of side scan backscatter intensity with grain size distribution of shelf sediments, New Jersey margin. Geo-Mar. Lett. 20, 43-49. 
Goff, J.A., Kraft, B.J., Mayer, L.A., Schock, S.G., Sommerfield, C.K., Olson, H.C., Gulick, S.P.S., Nordfjord, S., 2004. Seabed characterization on the New Jersey middle and outer shelf: correlatability and spatial variability of seafloor sediment properties. Mar. Geol. 209, 147-172.

Groupe Galice, 1979. The continental margin off Galicia and Portugal: acoustical stratigraphy, dredge stratigraphy, and structural evolution. In: Sibuet, J.C., Ryan, W.B.F., et al. (Eds.) Init. Repts. DSDP, 47, Pt. 2: Washington (U.S. Govt. Printing Office): 633-662.

Hellequin, L., Boucher, J.M., Lurton, X., 2003. Processing of high-frequency multibeam echo sounder data for seafloor characterization. IEEE J. Oceanic Eng. 28 (1), 78-89.

Hernández-Molina, F.J., Llave, E., Ercilla, G. ; Maestro, A., Medialdea, T., Ferrín, A., Somoza, L., Gràcia, E., Masson, D.G., García, M.; Vizcaino, A., León, R., This volume. Recent sedimentary processes in the Galicia Bank (NW Iberian Margin): An integrated study using high-resolution marine geophysical methods. Mar. Geol.

Kostylev, V.E., Courtney, R.C., Robert, G., Todd, B.J., 2003. Stock evaluation of giant scallop (Placopecten magellanicus) using high-resolution acoustics for seabed mapping. Fish. Res. 60 (2-3), 479-492.

Llave, E., García, M., Pérez, C., Sayazo, M., Farrán, M., León, R., Maestro, A., Medialdea, T., Somoza, L., Hernández-Molina, F.J., Álvarez, R., Durán, R., Mohamed, K., This volume. Morphological feature analyses of the Prestige half-graben on the SW Galicia Bank. Mar. Geol.

Lewis, C.F.M., Mayer, L.A.; Mukhopadhyay, P.JK., Kruge, M.A., Coakley, J.P., Smith, M.D., 2000. Multibeam sonar backscatter lineaments and anthropogenic organic components in lacustrine silty clay, evidence of shipping in western Lake Ontario. Int. J. Coal Geol. 43, 307-324.

Loncke, L., Gaullier, V., Bellaiche, G., Mascle, J., 2002. Recent depositional patterns of the Nile deep-sea fan from echo-character mapping. AAPG Bull. 86 (7), 1165 1186.

Lurton, X., 2002. An Introduction to Underwater Acoustic. Principles and Applications. Springer-Verlag, $347 \mathrm{pp}$.

Mauffret, A., Boillot, G., Auxietre, J.L., Dunand, J.P., 1978. Evolution structurale de la marge continentale au Nord-Ouest de la Péninsule Ibérique. Bull. Soc. Geol. Fr. 20, 375-388.

Mitchell, N.C., 1996. Processing and analysis of Simrad multibeam sonar data. Mar. Geophys. Res. 18 (6), 729-739.

Mitchell, N.C., Clarke, J.E.H., 1994. Classification of seafloor geology using multibeam sonar data from the Scotian Shelf. Mar. Geol. 121, 143-160.

Nitsche, F.O., Bell, R., Carbotte, S.M., Ryan, W.B.F., Flood, R., 2004. Process-related classification of acoustic data from the Hudson River Estuary. Mar. Geol. 209, 131-145.

Orange, D.L., Yun, J., Maher, N., Barry, J., Greene, G., 2002. Tracking California seafloor seeps with bathymetry, backscatter and ROVs. Cont. Shelf Res. 22 (16), 2273-2290.

Sager, W.W., MacDonald, I.R., Hou, R.S., 2003. Geophysical signatures of mud mounds at hydrocarbon seeps on the Louisiana continental slope, northern Gulf of Mexico. Mar. Geol. 198, 97-132. 
Somoza, L., Díaz-del-Río, V., León, R., Ivanov, M., Fernández-Puga, M.C., Gardner, J.M., Hernández-Molina, F.J., Pinheiro, L.M., Rodero, J., Lobato, A., Maestro, A., Vázquez, J.T., Medialdea, T., Fernández-Salas, L.M., 2003. Seabed morphology and hydrocarbon seepage in the Gulf of Cádiz mud volcano area: Acoustic imagery, multibeam and ultrahigh resolution seismic data. Mar. Geol. 195, 153-176.

Todd, B.J., Fader, G.B.J., Courtney, R.C., Pickrill, R.A., 1999. Quaternary geology and surficial sediment processes, Browns bank, Scotian shelf, based on multibeam bathymetry. Mar. Geol. 162, 165-214.

Urgeles, R., Locat, J., Schmitt, T., Hughes Clarke, J.E., 2002. The July 1996 flood deposit in the Sanguenay Fjord, Quebec, Canada: implications for sources of spatial and temporal backscatter variations. Mar. Geol. 184, 41-60.

Urick, R.J., 1975. Principles of Underwater Sound. McGraw Hill, New York, 384 pp.

Valentine, P.C., Cochrane, G.R., Scanlon, K.M., 2003. Mapping the seabed and habitats in National Marine Sanctuaries - Examples from the East, Gulf and West Coasts. Mar. Technol. Soc. J. 37 (1), 10-17.

Vázquez, J.T., Medialdea, T., Ercilla, G., Somoza, L., Estrada, F., Fernández Puga, M.C., Gallart, J., Gràcia, E., Maestro, A., Sayago, M., This volume. Cenozoic deformational structures on the Galicia Bank Region (NW Iberian continental margin). Mar. Geol.

\section{FIGURE CAPTIONS}

Fig. 1. Location and detailed bathymetric map of the study area where main morphological features are indicated. SW: Sedimentary wedge; SL: Sedimentary lobe; IC: Inter-lobe channel; MC: Main channel.

Fig. 2. A) Side scan sonar backscatter map obtained with the multibeam system over the southwestern part of the Galicia Bank B) Mean backscatter intensity map. The bow and stern location of the Prestige tanker are indicated by the arrows. 
Fig. 3. High-resolution side scan sonar TOBI mosaic (A) and interpretation (B). The location of the bow and the stern of the Prestige oil tanker are marked with a red point (after Hernández Molina et al., this volume).

Fig. 4. A) 3D image integrating bathymetry and mean backscatter by using a greyscale. The bow and stern of the Prestige tanker are marked with arrows. White box outlines a detailed segment depicted in B).

Fig. 5. Backscatter map displayed in greyscale, where low backscatter is shown in white colour and high backscatter in dark grey. Location of gravity cores is superposed. Bathymetric contours are spaced every 50 m. BO: Basement outcrop; SW: Sedimentary wedge; SL: Sedimentary lobe; IC: Inter-lobe channel; MC: Main channel.

Fig. 6. Correlation between backscatter intensity and coarse $\%$ for gravity cores collected in the study area. Light grey shadows highlight evident linear trends (P1 and P2).

Fig. 7. Correlation between backscatter intensity and density (A) and compressional velocity (B) for gravity cores collected in the study area. Light grey shadows highlight evident linear trends (P1 and P2).

Fig. 8. Air gun seismic profile RG1-27 where a coloured scale has been assigned to amplitude values. Core locations and mean backscatter strength values are superposed. See Fig. 4 for location. Inset corresponds to a detail of the zone where the bow lies, 
which is marked by an amplitude anomaly (red colour) at the seabottom and in the water column.

Fig. 9. A) Shaded mean depth map obtained with a multibeam system of the Prestige's bow area (www.icm.csic.es/geo/gma/ergap/ergap.html); B) Bathymetric map corresponding to the image show in A), where slope gradient is displayed in a colour scale. On both images, it is clear how the Prestige tanker slid down after touching the seabed, favoured by the steep slope and the muddy sediments. The scar produced by the slide influences the geometry of the isobaths.

Table I. Characteristics of the seabed samples. Values of the parameters displayed are averaged for the upper $50 \mathrm{~cm}$ of each core (minimum length of the cores recovered) and mean backscatter intensity has been derived from a 100x100 m area around each core location. 


\begin{tabular}{|c|c|c|c|c|c|c|c|}
\hline CORE & $\begin{array}{c}\text { Backscatter } \\
\text { intensity (dB) }\end{array}$ & $\begin{array}{c}\text { Density } \\
\left(\mathbf{g} / \mathbf{c m}^{\mathbf{3}} \mathbf{)}\right.\end{array}$ & $\begin{array}{c}\text { Vp } \\
(\mathbf{m} / \mathbf{s})\end{array}$ & $\begin{array}{c}\text { Sand+gravel } \\
\mathbf{( \% )}\end{array}$ & $\begin{array}{c}\text { Silt+clay } \\
(\mathbf{\%})\end{array}$ & Sediment type & Location \\
\hline 1TG1 & -33.55 & 1.52 & 1491.9 & 10.44 & 87.09 & Muds & Inter-lobe chann \\
\hline 1TG2 & -37.12 & 1.91 & 1236.8 & 25.29 & 70.62 & Muddy sands and muds & Scarp \\
\hline 1TG3 & -36 & 1.64 & 1434.92 & 35.99 & 58.91 & Muddy sands and muds & Scarp \\
\hline 1TG4 & -35.55 & 1.57 & 1483.46 & 64.34 & 43.16 & Sands & Scarp \\
\hline 1TG5 & -35.7 & 1.84 & 1206.19 & 14.06 & 85.8 & Muds & Sedimentary lob \\
\hline 1TG6 & -34 & 1.6 & 1406.92 & 5.8 & 93.09 & Muds and muddy sands & Inter-lobe chann \\
\hline 1TG8 & -32.5 & 1.61 & 1445.99 & 14.09 & 87.85 & Muds & Sedimentary lob \\
\hline 1TG9 & -31.9 & 1.62 & 1351.7 & 9.49 & 88.34 & Muds & Inter-lobe chann \\
\hline 1TG10 & -32.97 & 1.58 & 1454.65 & 8.08 & 90.08 & Muds & Inter-lobe chann \\
\hline 1TG11 & -31.97 & 1.6 & 1478.46 & 10.49 & 87.39 & Muds & Sedimentary lob \\
\hline 2TG1 & -35.5 & - & - & 32.75 & 61.34 & Muds & Bank of Galicia cr \\
\hline 2TG2 & -33.2 & - & - & 6.94 & 82.10 & Muds & Main channel \\
\hline 2TG3 & -34 & - & - & 7.60 & 91.49 & Muds & Sedimentary lob \\
\hline 2TG4 & -34 & - & - & 8.02 & 91.07 & Muds & Sedimentary lob \\
\hline 2TG5 & -34 & - & - & 12.41 & 86.82 & Muds & Inter-lobe chann \\
\hline & & & & & & &
\end{tabular}

Table I 
ACCEPTED MANUSCRIPT
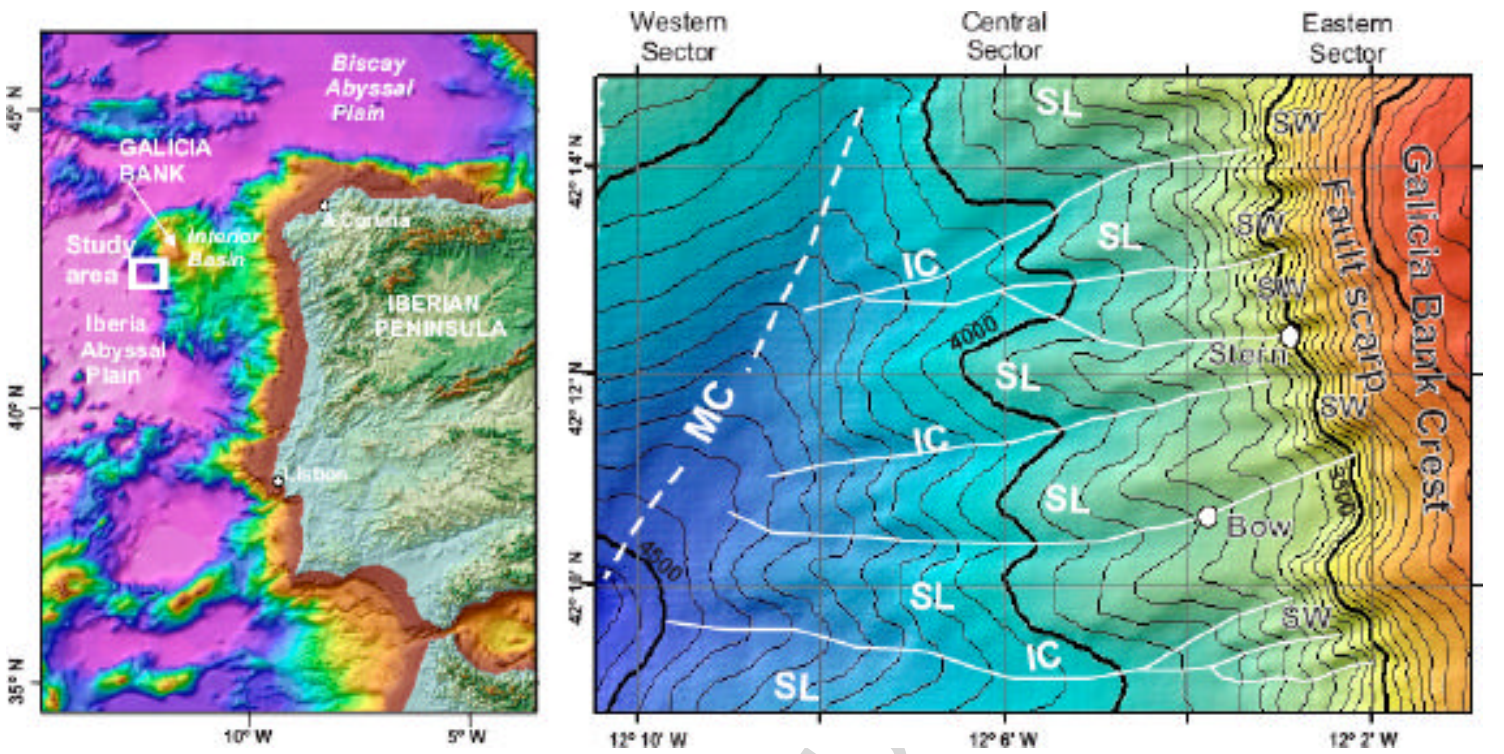
ACCEPTED MANUSCRIPT

A)

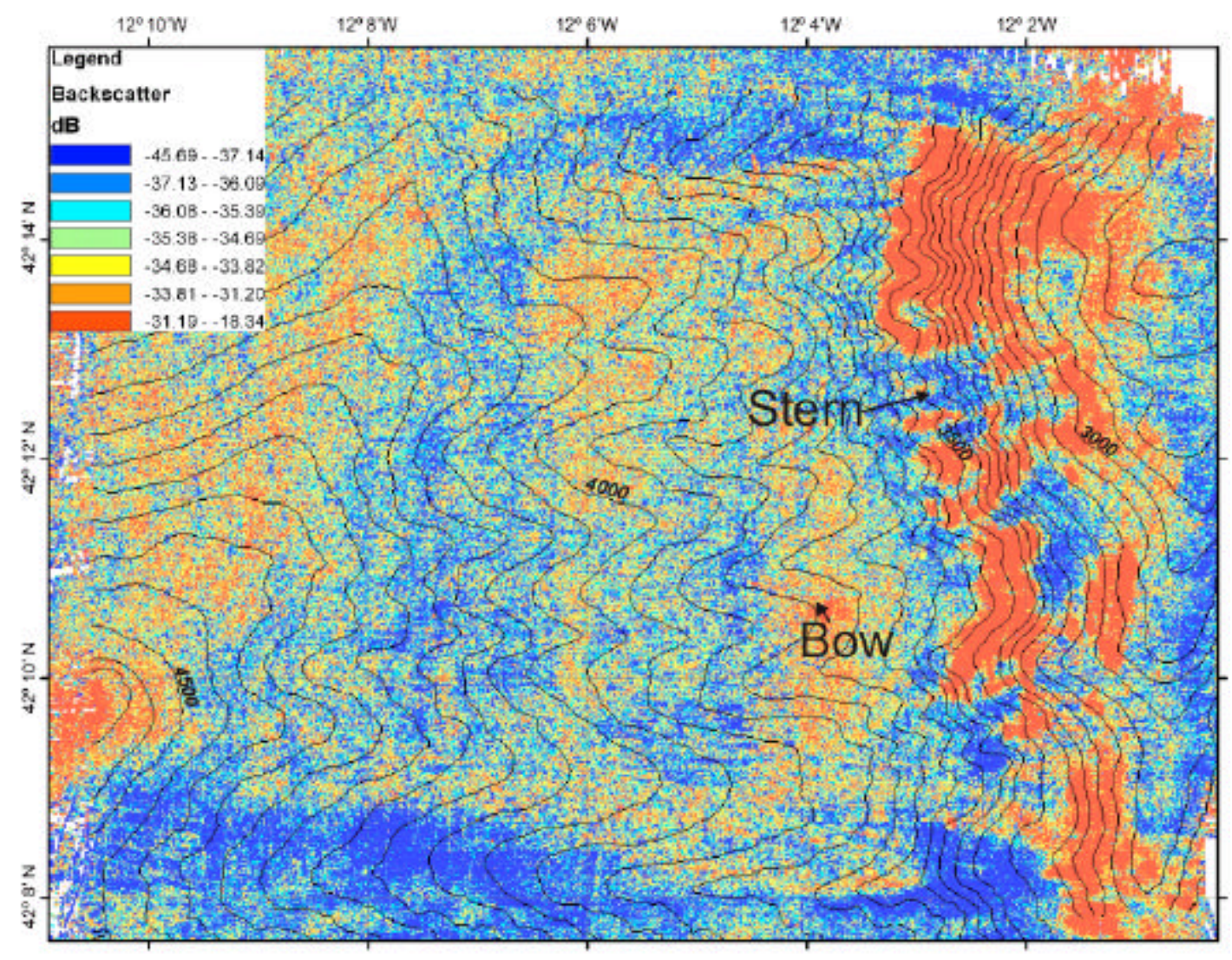

B)

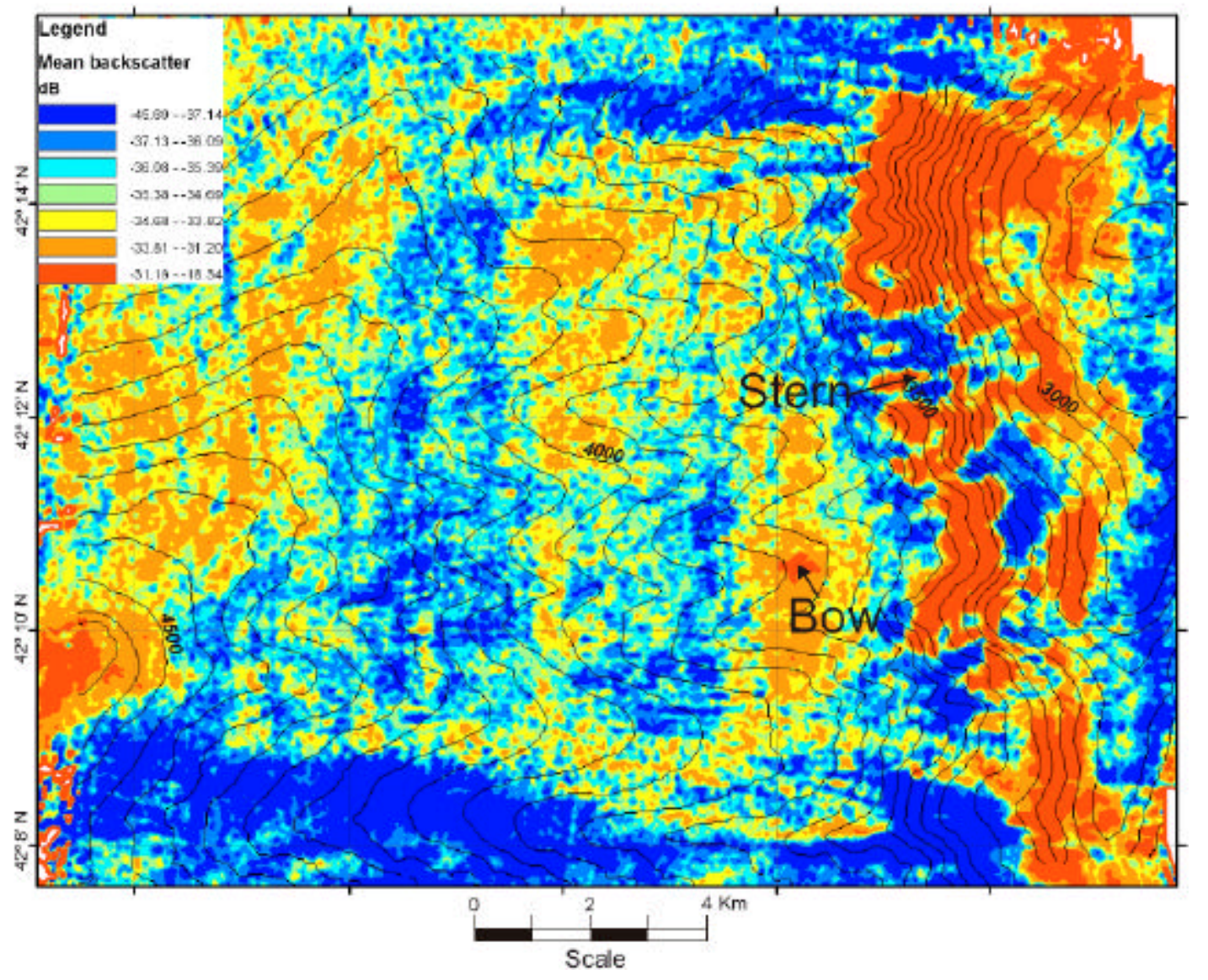


A)
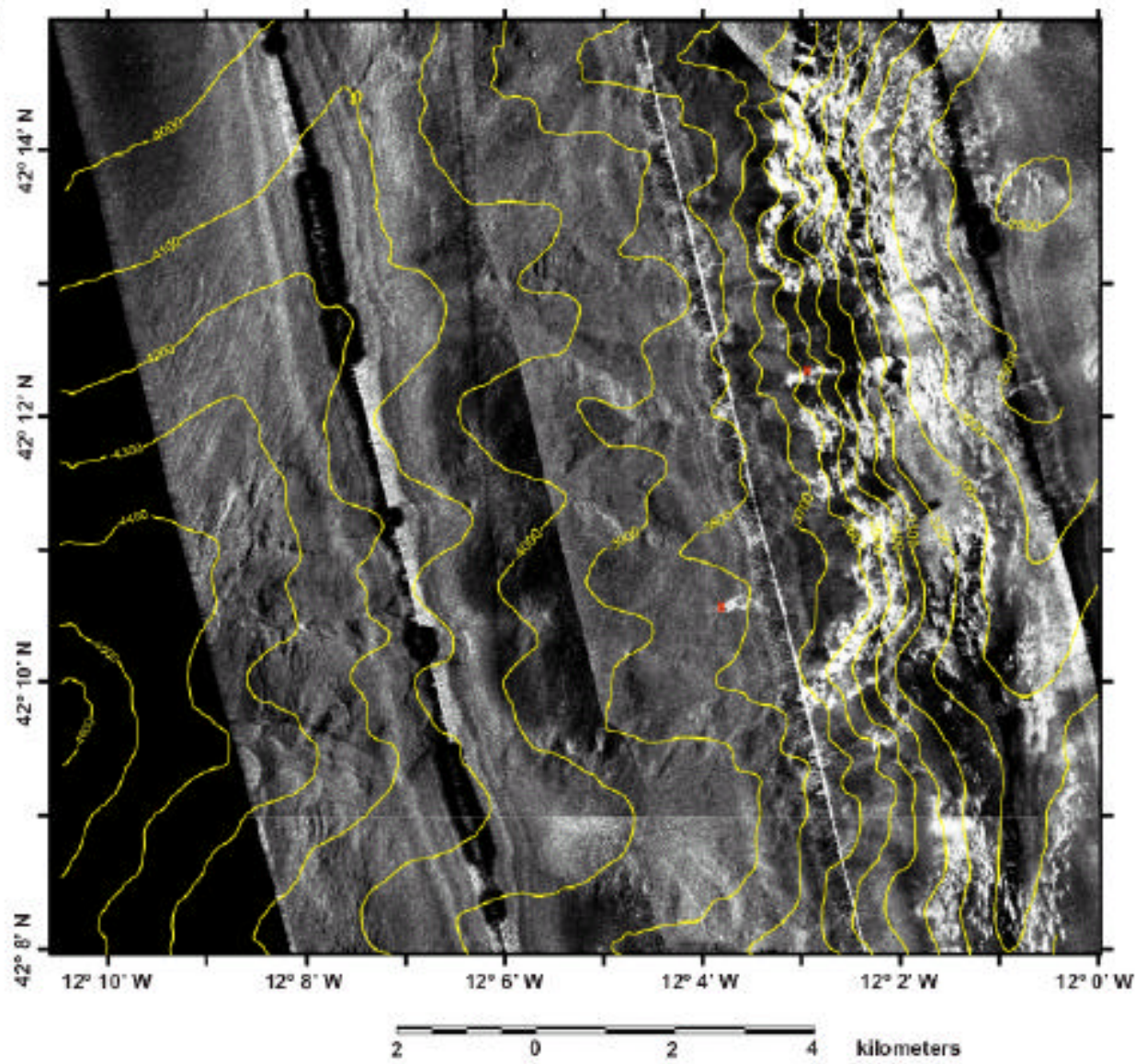

B)

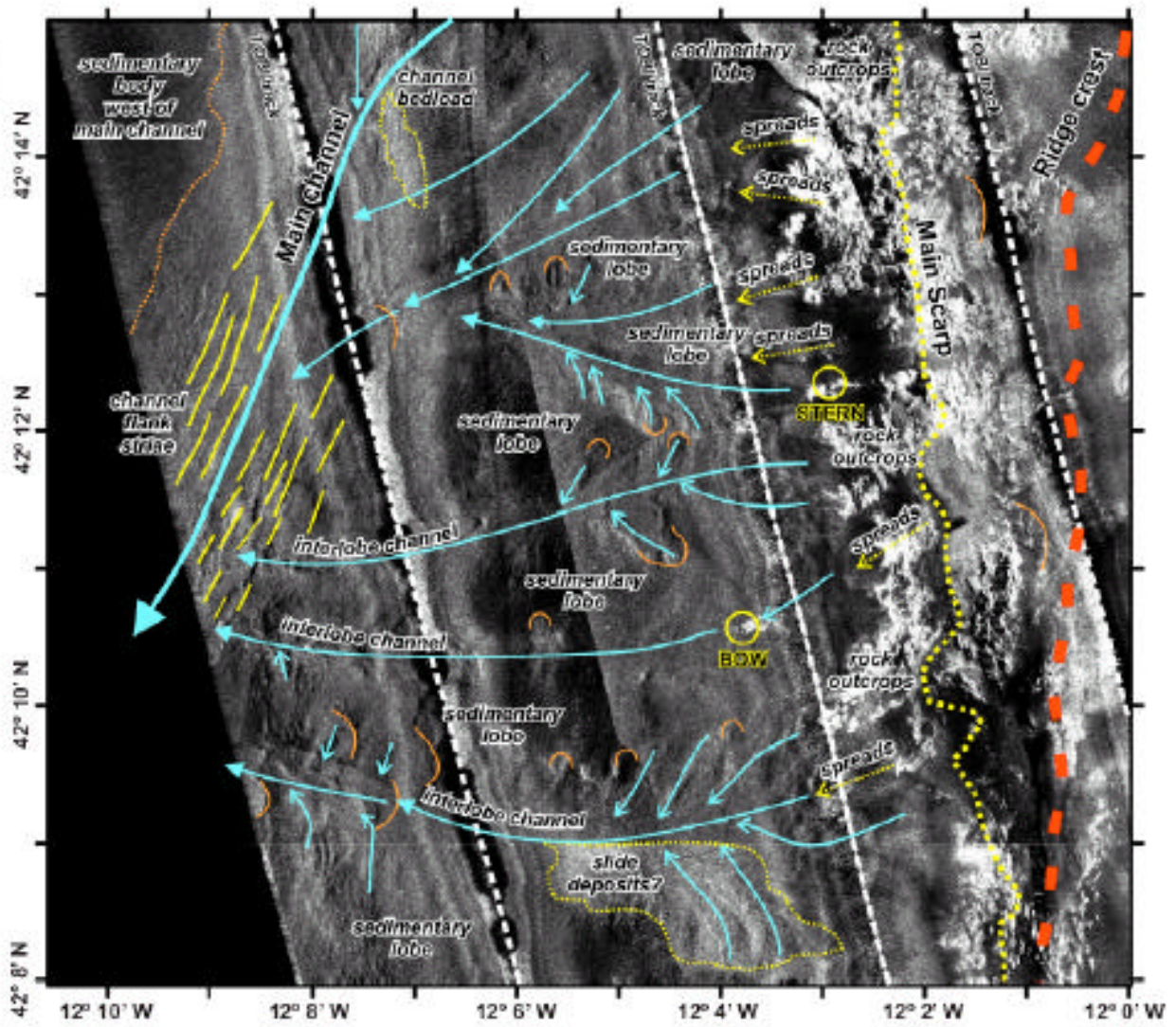




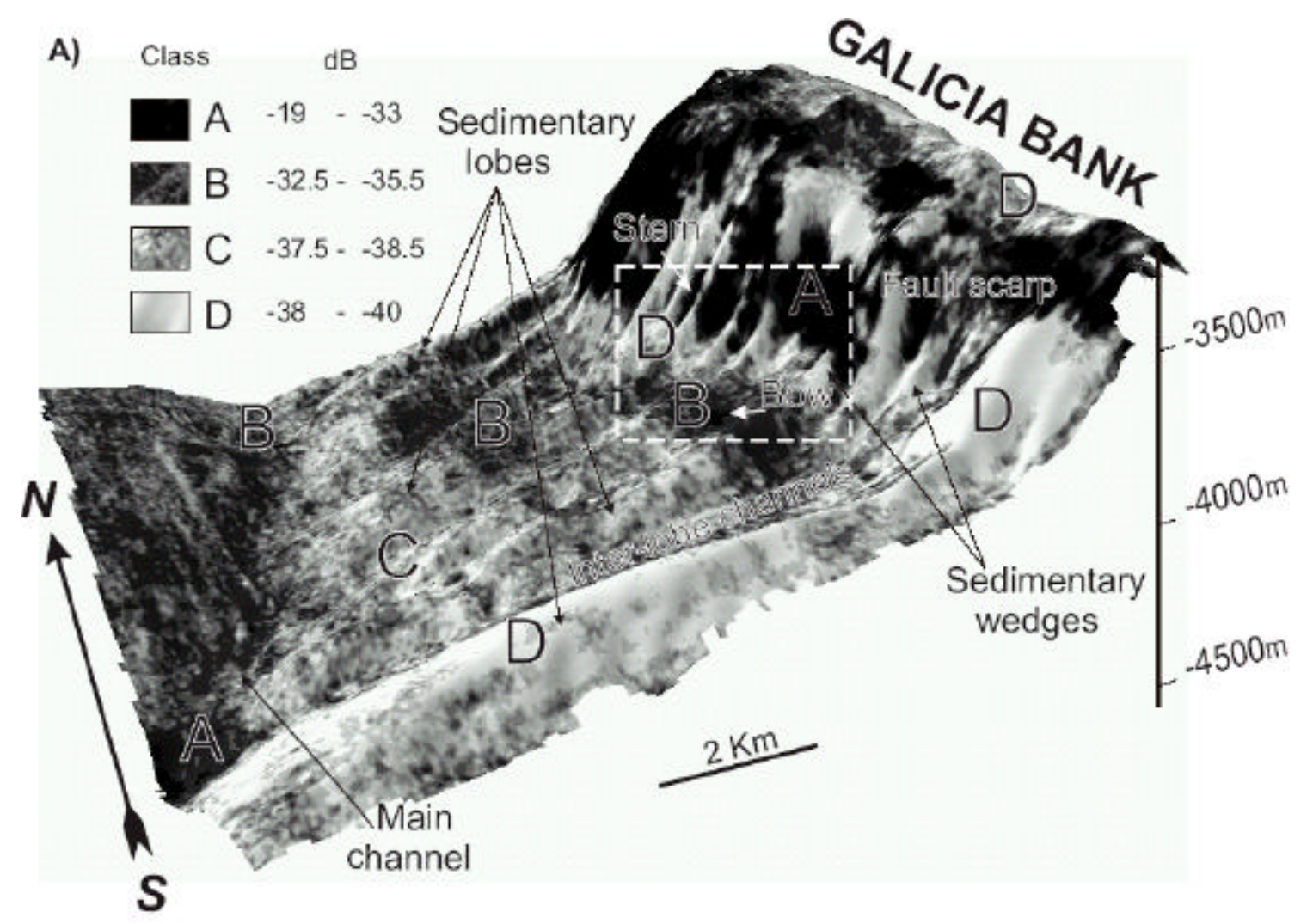

B)

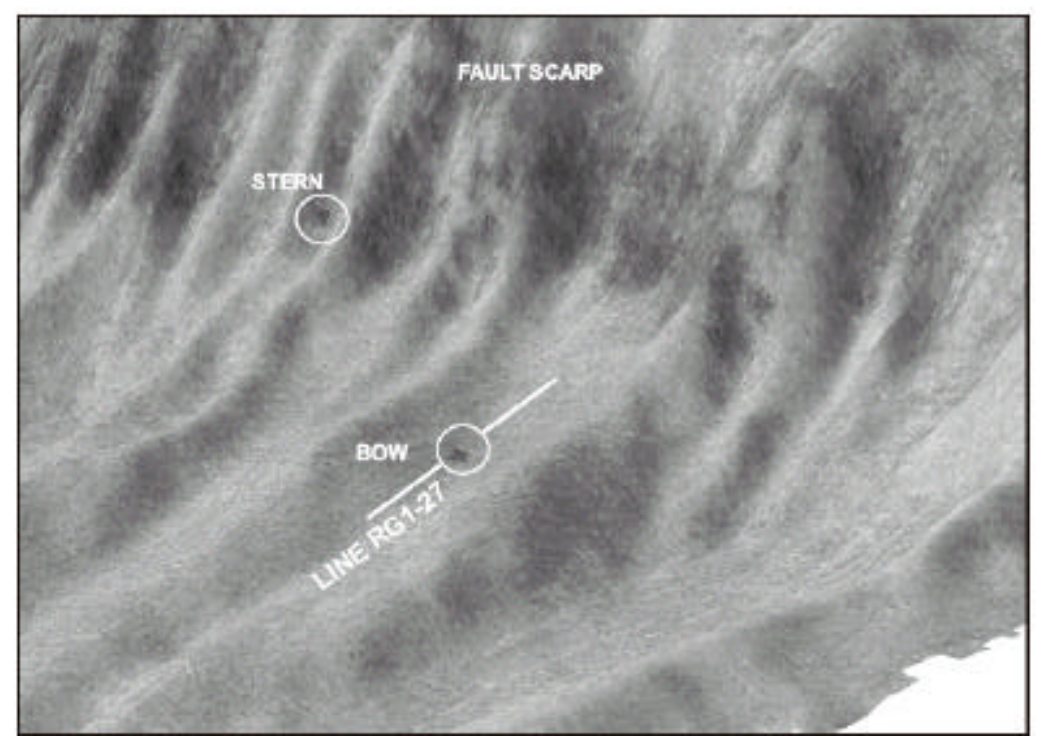




\section{ACCEPTED MANUSCRIPT}
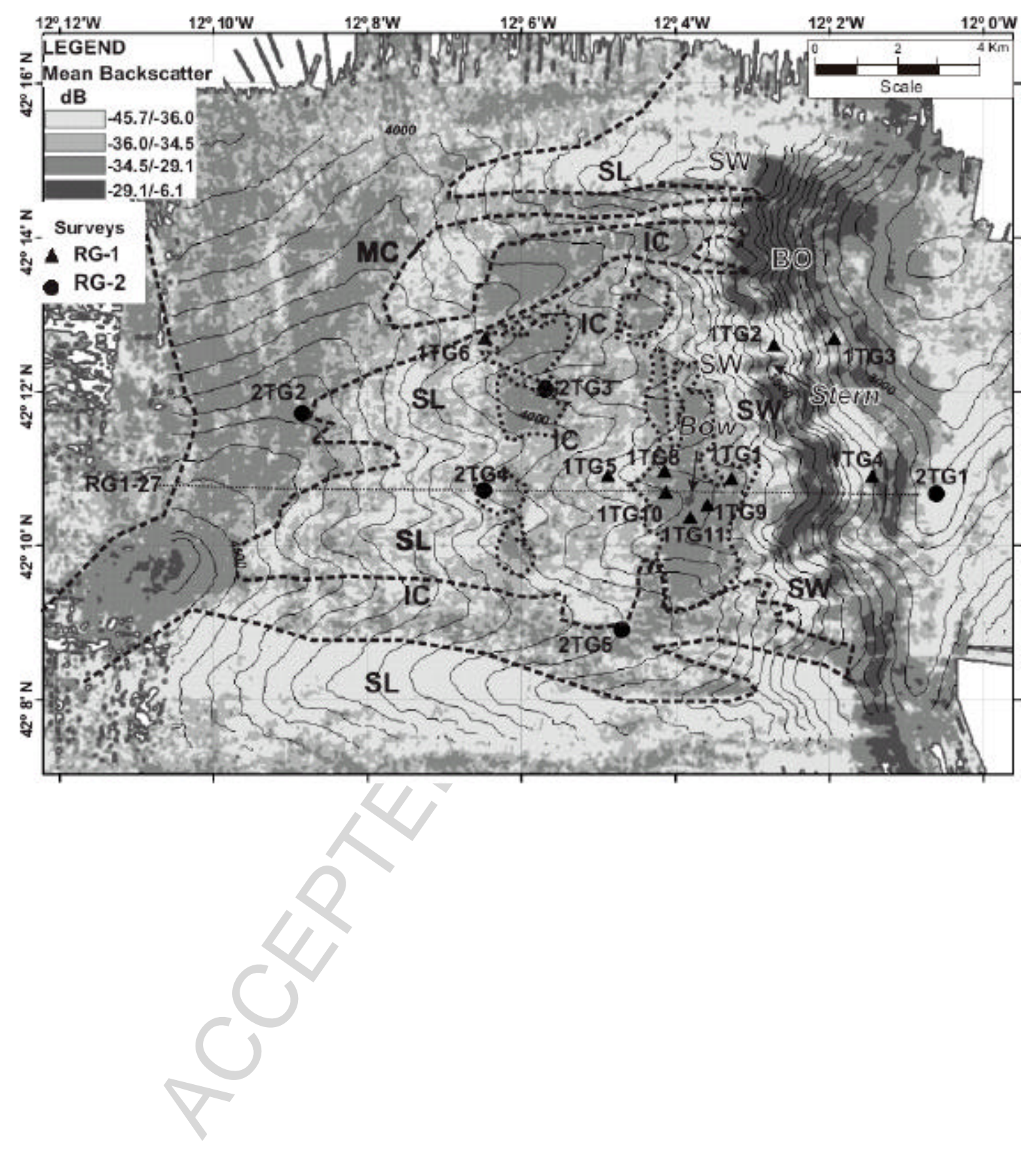


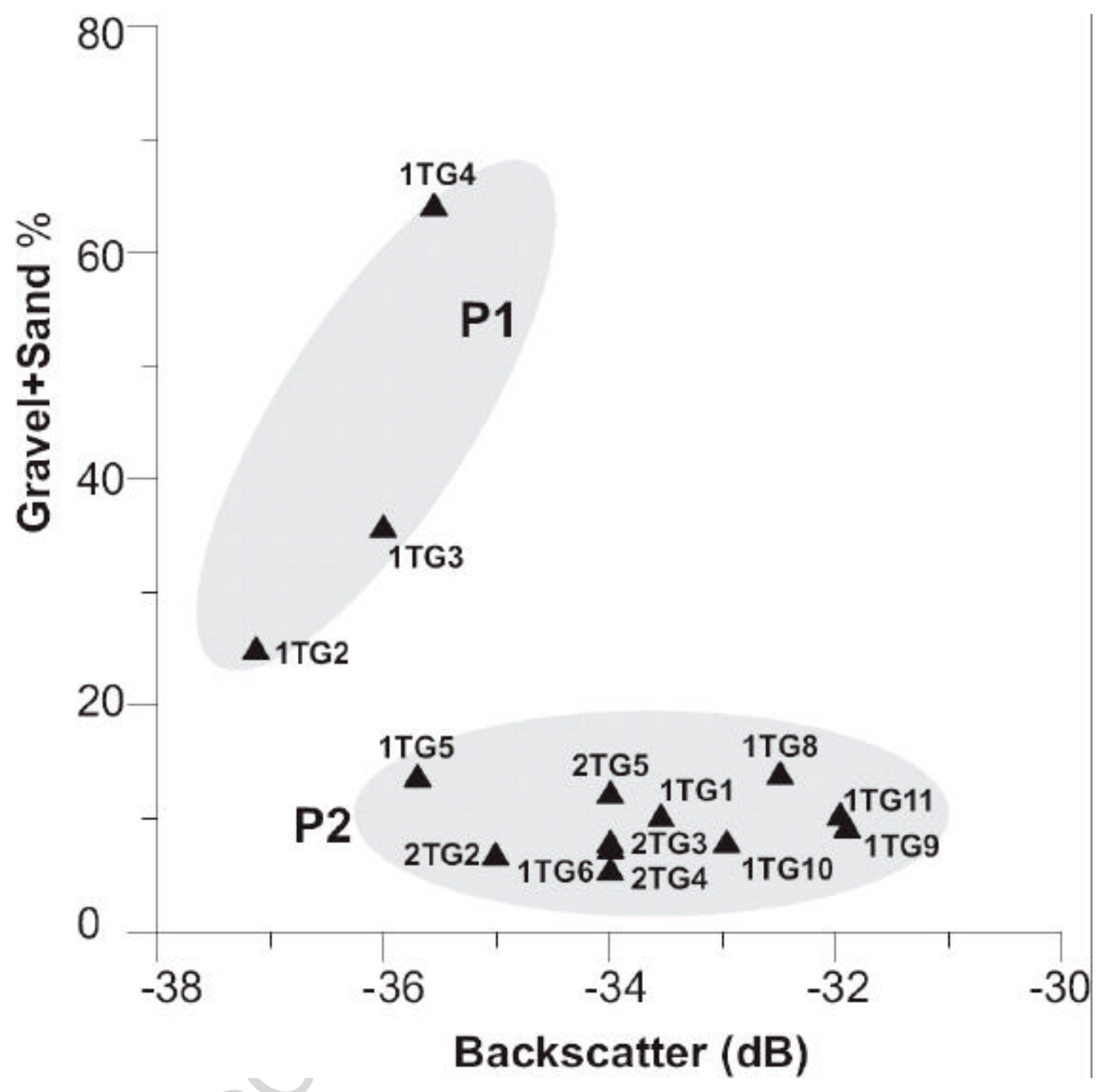



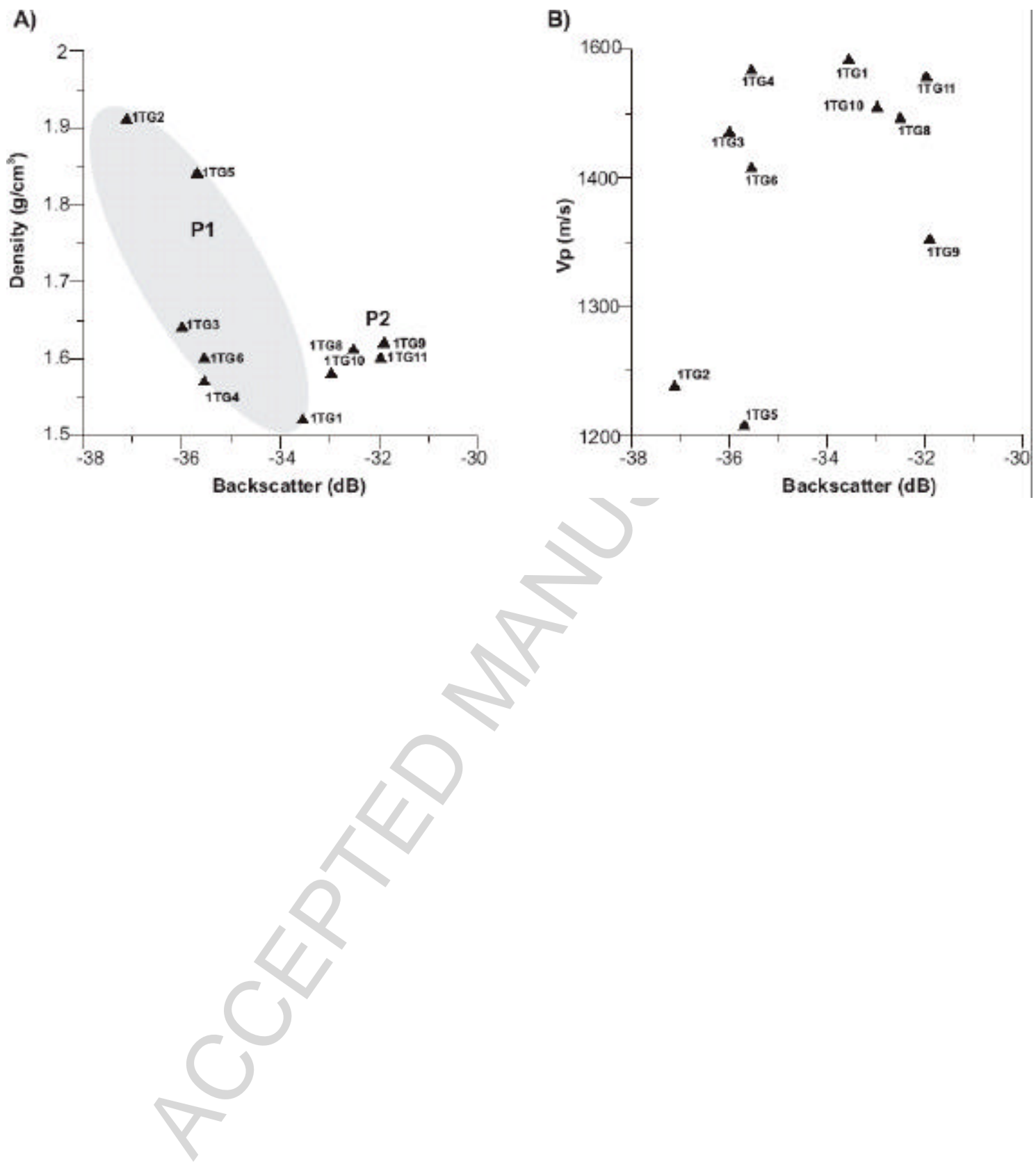


\section{ACCEPTED MANUSCRIPT}
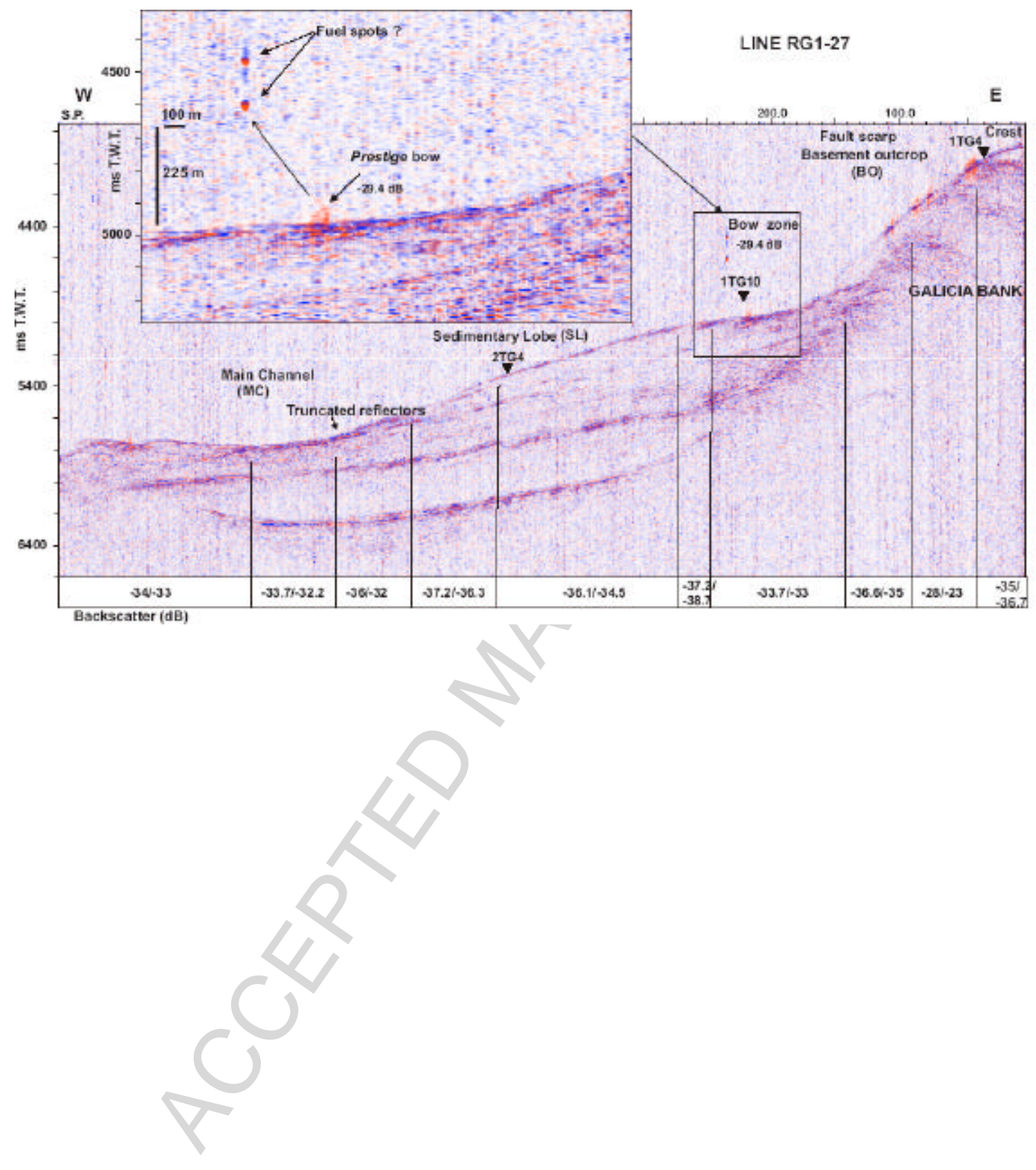
A)

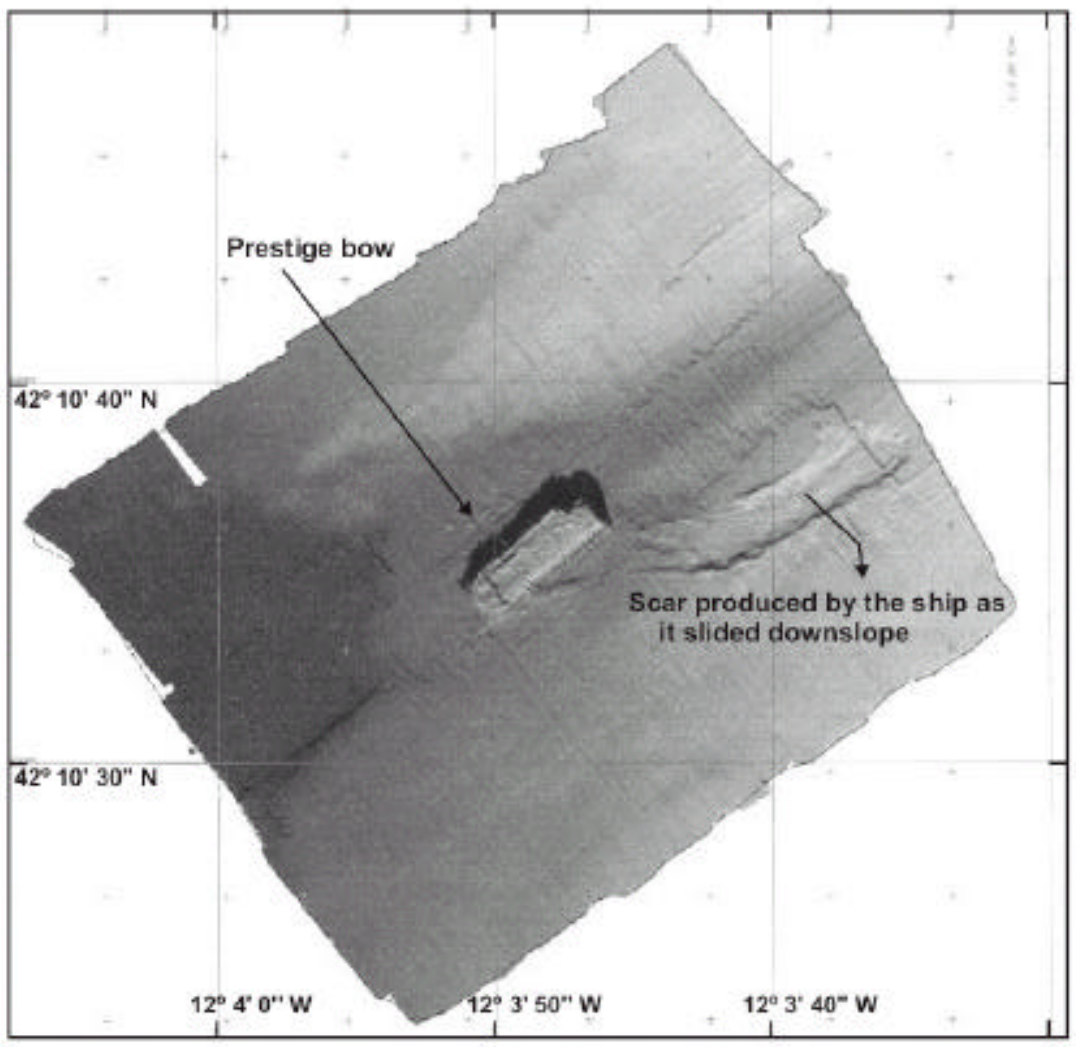

B)

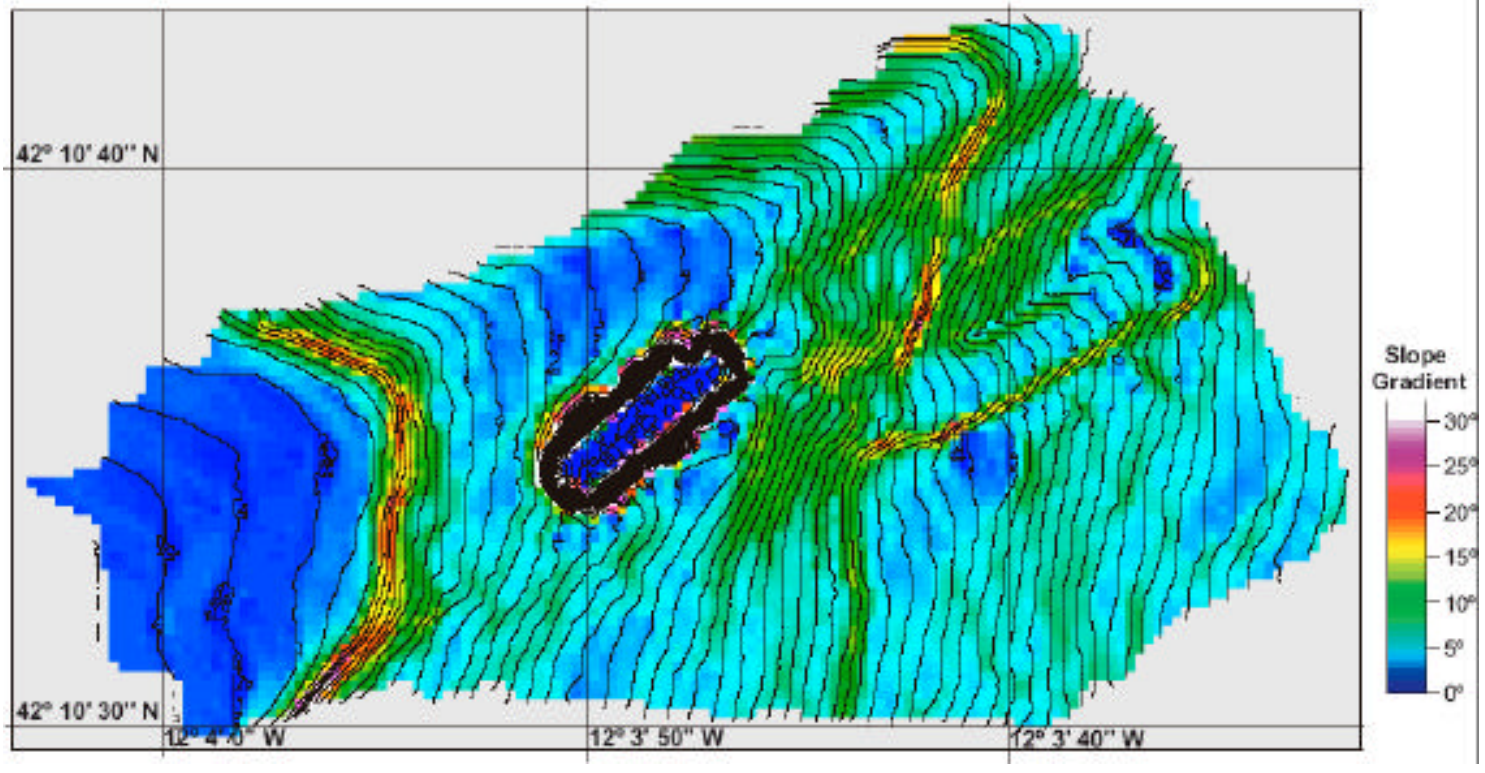

